\title{
Pelvic Radiation Therapy Induced Vaginal Stenosis: A Review of Current Modalities and Recent Treatment Advances
}

\author{
Guoda Varytè *(D) and Daiva Bartkevičienè
}

\author{
Clinic of Obstetrics and Gynaecology, Faculty of Medicine, Institute of Clinical Medicine, Vilnius University, \\ LT-03101 Vilnius, Lithuania; daivabartk@gmail.com \\ * Correspondence: g.varyte@gmail.com
}

check for updates

Citation: Varytè, G.; Bartkevičienè, D. Pelvic Radiation Therapy Induced Vaginal Stenosis: A Review of Current Modalities and Recent Treatment Advances. Medicina 2021, 57, 336. https://doi.org/10.3390/ medicina57040336

Academic Editor: Maurizio Serati

Received: 8 March 2021

Accepted: 29 March 2021

Published: 1 April 2021

Publisher's Note: MDPI stays neutral with regard to jurisdictional claims in published maps and institutional affiliations.

Copyright: (c) 2021 by the authors. Licensee MDPI, Basel, Switzerland. This article is an open access article distributed under the terms and conditions of the Creative Commons Attribution (CC BY) license (https:// creativecommons.org/licenses/by/ $4.0 /)$.
Abstract: Radiation-induced vaginal stenosis (VS) is a common side effect of pelvic radiotherapy (RT). RT-induced VS may have various negative effects on women's quality of life, in particular dyspareunia, decreased vaginal lubrication and difficulties in sexual intercourse. This narrative review provides the aspects of RT-induced VS pathogenesis, incidence, evaluation and associated risk factors. Available treatment modalities are discussed in the article, putting the focus on preliminary, although promising, experience in the use of hyaluronic acid and laser therapy in cancer survivors after pelvic RT.

Keywords: vaginal stenosis; pelvic radiotherapy; vaginal dilation therapy; hyaluronic acid; laser therapy

\section{Introduction}

Treatment of gynecological (vaginal, cervical or uterine) and anorectal cancers commonly requires pelvic radiation therapy (RT). Radiation-induced vaginal stenosis (VS) is a common side effect of pelvic RT and is characterized as an abnormal vaginal canal obstruction due to scar tissue formation [1]. The reported incidence of RT-induced VS varies from $1.2 \%$ to $88 \%$, depending on the patient, the type of cancer and treatment (brachytherapy versus pelvic RT, use of dilators, hormones, RT dose, etc.) [2]. According to the latest reports, in the first three years after pelvic RT for endometrial, cervical and anorectal cancer, the estimated rates of VS are respectively 50\%,60\% and 80\% [3-5]. This complication mostly occurs after combined treatment with brachytherapy (BT) and external beam radiotherapy (EBRT). In BT, tissue damage is equally proportioned throughout the whole vagina, whereas in ERBT some areas may be more affected than others. Radiation affects the vaginal epithelium, small vessels and connective tissues, causing local inflammation and cell death. This is followed by vaginal hyalinization and fibrosis due to decreased blood flow, tissue hypoxia, collagen deposition and loss of elastin. Thinned vaginal mucosa, lack of lubrication, processes of scarring and fibrosis leads to a shorter, dryer and less elastic vagina [6]. It is recognized that sexual dysfunction affects more than half of gynecological and anorectal cancer survivors, and at the time of cancer diagnosis some women are young and sexually active [7]. RT-induced VS may have various negative effects on a patient's quality of life, in particular dyspareunia, decreased vaginal lubrication and difficulties in sexual intercourse. As for the health specialists, RT-induced VS limits gynecological examination during the post-treatment period [8].

\section{Incidence of Pelvic Radiation Induced Vaginal Stenosis}

The described incidence of RT-induced VS varies and depends on the treatment elements, tumor and patient factors. Developing VS is dependent on the site of disease, RT modality and dose, coexisting chemotherapy, and other factors of the patient, such as age or constitutional radio-sensitivity of the tissues. The incidence of RT-induced VS is principally based on small patient groups and retrospective data, also it depends on VS evaluation methods and used grading systems [9]. The reported incidence of RT-induced VS varies 
from $1.2 \%$ to $88 \%$ [2]. At this time RT-induced VS is considered a well-known toxicity following pelvic RT. A retrospective study reported a 38\% incidence of VS in women treated with pelvic RT and/or vaginal RT for cervical cancer (stages IB to IV). The study reported that mostly VS results in the first year after treatment [10]. According to other studies, VS continuously develops with time, meaning that mild VS occurs in the first year, and moderate or severe VS-three years after the treatment is finished [11]. RT-induced VS in cancer survivors for rectal and anal cancer is less described in the scientific literature. A study conducted by Son et al. reported that $2 / 3$ of patients developed VS following the RT for rectal and anal cancer [12]. Prior studies reported rates of $27.1 \%$ (moderate VS) and $37.1 \%$ (severe VS) in female patients with anal cancer after chemoradiation treatment [13].

\section{Pathogenesis}

The fast cell turnover of the vulvar and vaginal epithelium supports exfoliation of the outlying layers of non-dividing cells and causes the epithelium to become easily harmed by the radiation treatment. Radiation toxicity is defined by two phases: the acute reaction midst radiotherapy course and late reaction several months after finishing the treatment. In comparison, the late reaction might proceed from the acute reaction or occur after an asymptomatic period of at least three months [14].

VS is a consequence of direct RT injury to the vaginal mucosa. Damage to the small blood vessels and surrounding connective tissues causes decreased blood circulation. This is followed by hypoxia of the vaginal tissues and the progression of telangectasia. Vaginal wall hyalinization and fibrosis forms due to collagen formation in the elastic fibers that compose the vaginal connective tissues. Vaginal atrophy results in a lack of lubrication and thinning of the vaginal mucosa, while decreased vaginal elasticity is due to scarring, circumferential fibrosis and the development of adhesions. For some women, vaginal contractions, narrowing, shortening or total obliteration might occur if vaginal adhesions are not broken down. A reduced or absent ovarian function may lead to estrogen shortage, which further lessens vaginal lubrication and elasticity, intensifies vaginal mucosal thinning and atrophy [15].

\section{Evaluation of RT-Induced VS}

During regular gynecological follow-up visits, detailed information related to vaginal changes is usually picked. However, there is no concise agreement or protocol available for the classification, documentation or grading of radiation induced vaginal injuries and VS. The International Clinical Guideline Group suggested using common terminology criteria for adverse events (CTCAE) and late effects of normal tissues, subjective, objective, management, analytic (LENT SOMA) as measurement tools for defining RT-induced VS However, CTCAE is not specific to RT-induced vaginal injuries (Table 1). The European Organization for the Research and Treatment of Cancer (EORTC) and the US-based Radiation Therapy Oncology Group (RTOG) designed the LENT-SOMA scale. This scale assesses RT side effects, addressing the subjective symptoms of the patient, objective clinical findings, management and analytic investigations (Table 2). The LENT-SOMA grading system demonstrates that symptoms after RT might be an outcome from multiple pathologies and VS is only one integral $[2,16,17]$. 
Table 1. Common terminology criteria for adverse events (CTCAE) for vaginal stricture. Version 5.0.

\begin{tabular}{|c|c|c|c|c|c|}
\hline CTCAE Term. & Grade 1 & Grade 2 & Grade 3 & Grade 4 & Grade 5 \\
\hline $\begin{array}{c}\text { Vaginal stricture } \\
\text { Definition } \\
\text { A disorder characterized } \\
\text { by a narrowing of the } \\
\text { vaginal canal. }\end{array}$ & $\begin{array}{l}\text { Asymptomatic; } \\
\text { mild vaginal } \\
\text { shortening or } \\
\text { narrowing }\end{array}$ & $\begin{array}{l}\text { Vaginal narrowing } \\
\text { and/or shortening } \\
\text { not interfering } \\
\text { with the physical } \\
\text { examination }\end{array}$ & $\begin{array}{l}\text { Vaginal narrowing } \\
\text { and/or shortening } \\
\text { interfering with the use } \\
\text { of tampons, sexual } \\
\text { activity or physical } \\
\text { examination }\end{array}$ & - & Death \\
\hline
\end{tabular}

Table 2. Radiation Therapy Oncology Group (RTOG)/European Organization for the Research and Treatment of Cancer (EORTC) late effects of normal tissues, subjective, objective, management (LENT-SOMA) scoring table for injury to the vagina.

\begin{tabular}{|c|c|c|c|c|c|}
\hline & Grade 1 & Grade 2 & Grade 3 & Grade 4 & Score \\
\hline \multicolumn{6}{|c|}{ Subjective } \\
\hline Dyspareunia & $\begin{array}{l}\text { Occasional and } \\
\text { minimal }\end{array}$ & $\begin{array}{l}\text { Intermittent and } \\
\text { tolerable }\end{array}$ & $\begin{array}{l}\text { Persistent and } \\
\text { intense }\end{array}$ & $\begin{array}{l}\text { Refractory and } \\
\text { excruciating }\end{array}$ & \\
\hline Dryness & Occasional & Intermittent & Persistent & Refractory & \\
\hline Bleeding & Occasional & Intermittent & Persistent & Refractory & \\
\hline Pain & $\begin{array}{l}\text { Occasional and } \\
\text { minimal }\end{array}$ & $\begin{array}{l}\text { Intermittent and } \\
\text { tolerable }\end{array}$ & $\begin{array}{l}\text { Persistent and } \\
\text { intense }\end{array}$ & $\begin{array}{l}\text { Refractory and } \\
\text { excruciating }\end{array}$ & \\
\hline \multicolumn{6}{|c|}{ Objective } \\
\hline Stenosis/length & $>2 / 3$ normal length & $\begin{array}{l}1 / 3-2 / 3 \text { normal } \\
\text { length }\end{array}$ & $\begin{array}{l}<1 / 3 \text { normal } \\
\text { length }\end{array}$ & Obliteration & \\
\hline Dryness & Asymptomatic & Symptomatic & $\begin{array}{l}\text { Secondary } \\
\text { dysfunction }\end{array}$ & & \\
\hline Ulceration/necrosis & Superficial, $\leq 1 \mathrm{~cm}^{2}$ & Superficial, $>1 \mathrm{~cm}^{2}$ & Deep ulcer & Fistulae & \\
\hline Atrophy & Patchy & Confluent & Nonconfluent & Diffuse & \\
\hline Appearance & $\begin{array}{l}\text { Telangiectasia without } \\
\text { bleeding }\end{array}$ & $\begin{array}{l}\text { Telangiectasia with } \\
\text { gross bleeding }\end{array}$ & & & \\
\hline Synechiae & & Partial & Complete & & \\
\hline Bleeding & & $\begin{array}{l}\text { On contact } \\
\text { Management }\end{array}$ & Intermittent & Persistent & \\
\hline Dyspareunia/Pain & $\begin{array}{l}\text { Occasional } \\
\text { non-narcotic }\end{array}$ & $\begin{array}{l}\text { Regular } \\
\text { non-narcotic }\end{array}$ & Regular narcotic & $\begin{array}{l}\text { Surgical } \\
\text { intervention }\end{array}$ & \\
\hline Atrophy & $\begin{array}{l}\text { Occasional hormone } \\
\text { cream }\end{array}$ & $\begin{array}{l}\text { Intermittent } \\
\text { hormone cream }\end{array}$ & $\begin{array}{l}\text { Regular hormone } \\
\text { cream }\end{array}$ & & \\
\hline Bleeding & Iron therapy & $\begin{array}{l}\text { Occasional } \\
\text { transfusion }\end{array}$ & $\begin{array}{l}\text { Frequent } \\
\text { transfusions }\end{array}$ & $\begin{array}{l}\text { Surgical } \\
\text { intervention }\end{array}$ & \\
\hline Stenosis & Occasional dilation & $\begin{array}{l}\text { Intermittent } \\
\text { dilation }\end{array}$ & Persistent dilation & $\begin{array}{l}\text { Surgical } \\
\text { reconstruction }\end{array}$ & \\
\hline Dryness & Hormone replacement & $\begin{array}{l}\text { Artificial } \\
\text { lubrication }\end{array}$ & & & \\
\hline Ulceration & Conservative & Debridement & $\mathrm{HBO} 2$ & $\begin{array}{l}\text { Graft, surgical } \\
\text { repair }\end{array}$ & \\
\hline
\end{tabular}

Scoring instructions

- $\quad$ Score the 17 SOM parameters with $1-4$. (Score $=0$ if there are no toxicities.)

LENT

Score:

- $\quad$ Total the scores and divide by 17.

\section{Analytic}

Magnetic resonance imaging Ultrasound

Examination under anesthesia Cytology/biopsy
Assessment of wall thickness, sinus and fistula formation. Assessment of wall thickness, sinus and fistula formation.

Y/N Date:

Y/N Date:

Assessment of wall diameter and length and mucosal surface.
Y/N Date: 


\section{Associated Risk Factors}

The rate and severity of VS is related to the factors of the treatment and the patient. These commonly include age, tumor extension to the vaginal walls and the extent of the vagina treated, radiation dose and a combination of BT with EBRT.

For cervical cancer survivors, there seems to be a direct link between higher radiation dose and vaginal injuries. So far, the widest published study involving 630 women with cervical cancer (from the international study on magnetic resonance imaging (MRI)-guided brachytherapy in locally advanced cervical cancer (EMBRACE) study), identified that the development of VS was associated with a rectovaginal reference point dose. Within 24 months, the estimated risk of developing symptomatic VS was $16 \%$ at 55 Gy rectovaginal reference point dose, $20 \%$ at $65 \mathrm{~Gy}, 27 \%$ at $75 \mathrm{~Gy}, 34 \%$ at $85 \mathrm{~Gy}$ and $43 \%$ with $95 \mathrm{~Gy}$ [5]. As for uterine cancer and BT, studies showed similar results. A prospective study conducted by Sorbe et al. concluded that vaginal brachytherapy at dose 9.0 Gy per fraction, compared with 6.0, 5.0, or 4.5 Gy per fraction for women with Stage I endometrial cancer was significantly related with shortening of the vagina. Subsequently in five years, shortening of the vagina was $79 \%$ against $60 \%, 50 \%$ and $31 \%$, respectively [18]. Further, fifteen years later, the same authors conducted a study of 290 women receiving 2.5 Gy versus 5.0 Gy 6 fractions brachytherapy for early-stage endometrial carcinoma. No significant changes in vaginal length were observed after five years in the 2.5 Gy group, whereas in the 5.0 Gy group, women experienced $\frac{1}{4}$ vaginal shortening on average [19].

For women diagnosed with endometrial or cervical cancer, it is assumed that a higher volume of vagina treated is associated with an increased risk of VS in the EMBRACE study for cervical cancer-the 24-month actuarial estimate for symptomatic VS was $21 \%$, and the extent of the tumor into the vagina was a considerable risk factor [5]. A few observational studies identified that a longer length of treated vaginal canal significantly increased the risk of VS for women with early-stage endometrial cancer receiving BT $[3,20]$. There is a lack of studies investigating the effects of RT on vaginal volume and/or portion in cases with pelvic tumors. However, it is known that the lower portion of the vagina has less tolerance to RT compared to the upper or middle portions. Consequently, women have an increased risk of vaginal injuries and VS after lower portion vaginal RT [21].

It is recognized that age $>50$ years increases the risk of VS for patients receiving pelvic/vaginal RT for cervical cancer [10]. Tobacco has also been identified as a potential patient-related risk factor [14]. This is seemingly possible given the widely known co-active effect of cigarette smoking and radiation reactions on normal tissues of the aero-digestive tract seen in numerous tumors, including cervical tumors [22]. A vaginal pallor reaction is also considered to be a risk factor, knowing that the pathophysiology is associated with atrophy, inflammation, lack of moisture and fibrosis [11].

Within the past few decades, the increased use of RT for vulvar cancer has significantly increased the rates of sexual dysfunction in vulvar cancer survivors. Narrowing of the vaginal introitus, pain and scarring impairs sexual function well before any evidence of vaginal stenosis is present [23,24]. VS in vulvar cancer survivors can be underreported as stenosis of the vaginal introitus creates physical boundaries for gynecological examination and sexual intercourse, therefore, proper vulvar reconstruction surgery is of major importance for these patients $[25,26]$.

\section{Interventions for Gynecologic and Anorectal Cancer Survivors}

\subsection{Vaginal Dilator Therapy}

The idea of vaginal dilator therapy (VDT) after pelvic RT is the early separation and prevention of the adhesions between the walls of the vaginal mucosa. VDT also stretches vaginal tissues and the canal, stimulates epithelial cell growth, preventing circumferential fibrosis and elastosis [27]. Many studies have found significant correlations between VDT and decreased risk of severe VS after pelvic RT for gynecological and anorectal cancers [3,2831]. Even though there is no high-level evidence, many reviews and guidelines support 
the use of VDT after pelvic RT, and dilators remain a generally agreed prevention for VS and are widely used in clinical practice [2,32-34].

There are various dilators available from medical supplies shops and many clinics or institutions provide their patients with dilators. Commercially available dilators made of a hard plastic or stainless steel might not be so comfortable for some women to use. Silicone dilators may be used as an alternative and there is a wide assortment of available colors and sizes [35]. As proposed by the International Clinical Guideline Group, women are recommended to start dilation with the smallest size dilator and proceed to larger sizes as VDT comes to be more comfortable. Depending on the cancer site, various shapes of dilators are available. For instance, flat end dilators for uterine and cervical cancer, low end for vaginal and rectal and pointed end for anal cancer. Instructions on how to use dilators may vary according to different clinics, yet the principles are alike. Insertion of the dilator vaginally should be gentle and applied with a water-soluble lubricant. When inserted to the uppermost region of the vagina, the dilator is gently rotated and then removed. VDT should not be administered with physical pressure and injuries to the vagina should be avoided [2].

Unfortunately, there is no specific approach to make VDT uniformly adapted, and recommendations in the scientific literature as to when, how and for how long VDT should be used is inconsistent. The general agreement on many aspects of VDT is lacking, including the regularity and duration of dilator therapy, the optimal VDT initiation time after completing RT, dilator sizes, insertion methods and the need of VDT in sexually active women $[2,32,33]$. In 2014, a consensus using the Delphi method on VDT for gynecological cancer survivors was reached. It was agreed that radiation oncologists should provide patients with the information about VDT prior treatment. Experts in this field suggested that qualified oncology nurses should provide practical and emotional support. Professionals recommended VDT to prevent vaginal adhesions, shortening and tightening, and it was encouraged to start VDT four weeks after completing RT treatment, perform VDT 2-3 times per week for 1-3 min and to continue VDT for 9 to 12 months. Dilators from a plastic material were recognized as the most suited for VDT [1]. In 2019, the Brazilian version of the consensus reached very much alike conclusions. It recommended VDT should last at least 5-10 $\mathrm{min}, 2-3$ times per week for an indefinite amount of time. However, this consensus did not reach a common agreement on when to start VDT [36]. To date, no existing evidence suggests starting VDT during RT [32].

\subsection{Hyaluronic Acid Therapy for Vaginal Side Effects after RT}

In preventing and neutralizing vaginal injuries after RT for gynecological and anorectal cancers, hyaluronic acid (HA) represents one of the most inventive ways to improve vaginal health in cancer survivors. Local application of HA favors epithelial regeneration, promotes vaginal trophism, elasticity and adequate lubrication. In addition, it sufficiently lessens sticking of the vaginal walls, consequently reducing the development of adhesions, obliteration of the vagina and VS HA is a polysaccharide and part of the of glycosaminoglycans participating in tissue repairment and the regeneration processes. HA is an essential part of the extracellular matrix, which is involved in the repair processes by maintaining sufficient amounts of hydration which assists in the process of cell migration [37]. Due to its high molecular mass, HA is not absorbed when applied on the skin or mucosa. It acts by modeling an invisible, thin and penetrable, visco-elastic outer surface film. This reticular film restores the moisture in the mucosa maintaining the main components of a youthful and healthful tissue, like smoothness, tonicity and elasticity [38]. To this day, HA is extensively used in the clinical practice of various medical branches due to its high level of safety, no contraindications or reports of interactions with other medications [39]. Different vaginal products with HA have been studied with promising results in non-cancer women after menopause [40-42].

Several authors investigated the effect of local HA administration and reported reduced treatment related symptoms and vaginal atrophy in patients treated with RT for 
gynecological cancers. Cassaro et al. examined 45 women with gynecological cancer treated with EBRT with/without vaginal BT. Local treatment with vaginal ovules containing HA reduced dyspareunia, vaginal atrophy, lack of moisture, VS and adhesions [43]. In a study conducted by Dinicola et al., 45 women with cervical cancer treated surgically, with chemotherapy, BT and EBRT received local treatment with HA. Biopsies two months later showed substantially reduced inflammation, fibrosis, cell atypia, bleeding and mucositis [44]. Markowska et al. investigated 37 patients with endometrial cancer after a vaginal BT with complaints of dyspareunia, inflammatory, necrotic lesions and adhesions in the vagina. The patients were administered HA vaginal suppositories, and $86.5 \%$ of enrolled patients reported vaginal health improvement after the treatment [45]. In a recent study done by Carter et al. 43 patients with a history of endometrial cancer at least one month after RT (EBRT or vaginal BT) were administered HA containing gel. HL moisturization daily for the first two weeks, and then three times a week until 12-14 weeks significantly improved sexual function and vulvovaginal health [46]. Delia et al. attempted to assess the ability of HA to reduce the side effects of RT for 180 cervical cancer patients. Women in the control group reported the onset and worsening of all symptoms from moderate to severe (inflammation, dryness, dyspareunia), whereas in the group treated with HA suppositories, nearly $90 \%$ of women reported none or mild grade symptoms [47]. A study conducted by Laliscia et al. enrolled 126 patients with endometrial cancer who underwent adjuvant vaginal BT and aimed to analyze the effect of HA ovules in the prevention of acute and late vaginal toxicities. The study's results suggested that patients with intermediate risk endometrial cancer receiving adjuvant vaginal BT after surgery benefited clinically from local HA treatment [48].

\subsection{Laser Therapy for Vaginal Side Effects after RT}

Over the last few years, intravaginal laser therapy showed promising results on sexual health and management of symptoms produced by menopausal genital atrophy. It appears that laser therapy effectively improves sexual function (sexual desire, dyspareunia, vaginal dryness, etc.) and restores vaginal health to a premenopausal state [49-51]. Particularly, the CO2 laser is able to activate an acute thermo-ablative or non-ablative effect that stimulates the synthesis of the matured components of collagen, fibroblast proliferation and extracellular matrix that increase vaginal wall elasticity and hydration [52].

There is a lack of studies analyzing vaginal health improvement after laser therapy for patients treated with RT after gynecological and anorectal cancer. Many researchers analyzing intravaginal laser devices in healthy postmenopausal women extrapolate their results to cancer survivors. They propose a theory that most cancer survivors may benefit from intravaginal laser therapy, particularly when local or systemic treatment with estrogen is contraindicated [53]. In a prospective study, Perrone et al. investigated 43 women with severe vaginal shortening, stenosis and atrophy after treatment with EBRT and/or BT for pelvic tumors. Three intravaginal non-ablative $\mathrm{CO}_{2}$ laser treatment sessions were scheduled one month apart and all procedures were well tolerated. During the follow up, six months after the last treatment session with the intravaginal laser, examiners observed a progressive increase in vaginal length and Vaginal Health Index (WHI). The authors concluded that intravaginal laser therapy is a promising treatment approach for vaginal injuries for women following pelvic RT, but more randomized clinical trials are needed to confirm the results [54]. A very recent pilot study done by Quick et al. investigated the efficacy of a fractional $\mathrm{CO}_{2}$ laser for reducing menopausal genitourinary symptoms in gynecological cancer survivors. The study reported no adverse events and, compared to the placebo, fractional $\mathrm{CO}_{2}$ laser therapy demonstrated preliminary evidence of an improvement in sexual function and safety in the gynecological cancer survivors group [55]. 


\subsection{Vaginal Estrogen Therapy}

Vaginal estrogen is widely used and is recognized as one of the most effective treatment options for menopausal vulvovaginal atrophy. It is proven to be safe in the general noncancer population [56,57]. Estrogen after RT is thought to promote vaginal epithelium regeneration and the effect may be more evident when vaginal estrogen is administered to the patient three or more months after the RT [14]. It is important to note that vaginal morphological changes caused by radiation have an impact on the effectiveness of vaginal estrogen therapy. A study done by Hofsjö identified that pelvic RT reduces estrogen and androgen protein expression in the vaginal mucosa, demonstrating that women treated with high dose RT have less potential to respond to estrogen treatment [58].

Evidence for the local and systemic hormone therapy management in gynecological cancer survivors is limited and can be challenging considering the risks for disease recurrence and adverse effects. Concerns exist regarding systemic or topical estrogens administered for patients with hormonally responsive tumors or an intact uterus. Based on what is known, estrogen therapy for early-stage endometrial carcinoma (Stages I-II) is reasonable, although no evidence exists supporting hormone therapy in late-stage endometrial carcinoma (Stages III-IV), and as a result, treatment with estrogen is not recommended [5961]. Cervical carcinoma is considered to be a hormonally non-responsive cancer. Ploch et al. conducted a study decades ago investigating 120 women with cervical carcinoma after surgery or RT (Stages I-II). After five years of follow up, the study reported no significant differences in cancer recurrence or survival rates in women receiving hormonal therapy versus the control group [62].

\section{Conclusions}

Radiation induced VS is a well-known side effect following pelvic RT for gynecological and anorectal cancers. Significant improvement in cancer treatment increases the number of cancer survivors who face long-term consequences on their sexual and general quality of life. In the clinical setting, VDT continues to be a globally accepted VS prevention strategy, however, a general agreement on many aspects of VDT is lacking. Although promising, the preliminary experience in the use of hyaluronic acid and laser therapy in cancer survivors after pelvic RT addresses the necessity of sexual rehabilitation for these patients. To confirm the results, further randomized clinical trials comparing and analyzing different treatment options and strategies are mandatory.

Author Contributions: G.V. writing—original draft preparation, data curation, investigation; D.B. conceptualization, writing — review and editing, visualization, project administration, supervision. All authors have read and agreed to the published version of the manuscript.

Funding: This research received no external funding.

Conflicts of Interest: The authors declare no conflict of interest.

\section{References}

1. Bakker, R.M.; Ter Kuile, M.M.; Vermeer, W.M.; Nout, R.A.; Mens, J.W.M.; Van Doorn, L.C.; De Kroon, C.D.; Hompus, W.C.; Braat, C.; Creutzberg, C.L. Sexual Rehabilitation After Pelvic Radiotherapy and Vaginal Dilator Use: Consensus Using the Delphi Method. Int. J. Gynecol. Cancer 2014, 24, 1499-1506. [CrossRef] [PubMed]

2. International Clinical Guideline Group. International Guidelines on Vaginal Dilation after Pelvic Radiotherapy; National Forum of Gynaecological Oncology Nurses; Owen Mumford: Oxon, UK, 2012.

3. Bahng, A.Y.; Dagan, A.; Bruner, D.W.; Lin, L.L. Determination of Prognostic Factors for Vaginal Mucosal Toxicity Associated With Intravaginal High-Dose Rate Brachytherapy in Patients With Endometrial Cancer. Int. J. Radiat. Oncol. $2012,82,667-673$. [CrossRef]

4. Mirabeau-Beale, K.; Hong, T.S.; Niemierko, A.; Ancukiewicz, M.; Blaszkowsky, L.S.; Crowley, E.M.; Cusack, J.C.; Drapek, L.C.; Kovalchuk, N.; Markowski, M.; et al. Clinical and treatment factors associated with vaginal stenosis after definitive chemoradiation for anal canal cancer. Pr. Radiat. Oncol. 2015, 5, e113-e118. [CrossRef] [PubMed] 
5. Kirchheiner, K.; Nout, R.A.; Lindegaard, J.C.; Haie-Meder, C.; Mahantshetty, U.; Segedin, B.; Jürgenliemk-Schulz, I.M.; Hoskin, P.J.; Rai, B.; Dörr, W.; et al. Dose-Effect relationship and risk factors for vaginal stenosis after definitive radio(chemo)therapy with image-guided brachytherapy for locally advanced cervical cancer in the EMBRACE study. Radiother. Oncol. 2016, 118, 160-166. [CrossRef]

6. Katz, A.; Njuguna, E.; Rakowsky, E.; Sulkes, A.; Sulkes, J.; Fenig, E. Early development of vaginal shortening during radiation therapy for endometrial or cervical cancer. Int. J. Gynecol. Cancer 2001, 11, 234-235. [CrossRef] [PubMed]

7. Sadovsky, R.; Basson, R.; Krychman, M.; Morales, A.M.; Schover, L.; Wang, R.; Incrocci, L. Cancer and Sexual Problems. J. Sex. Med. 2010, 7, 349-373. [CrossRef]

8. $\quad$ Bonner, C.; Nattress, K.; Anderson, C.; Carter, J.; Milross, C.; Philp, S.; Juraskova, I. Chore or priority? Barriers and facilitators affecting dilator use after pelvic radiotherapy for gynaecological cancer. Support. Care Cancer 2011, 20, 2305-2313. [CrossRef]

9. Morris, L.; Do, V.; Chard, J.; Brand, A.H. Radiation-induced vaginal stenosis: Current perspectives. Int. J. Women's Health 2017, 9, 273-279. [CrossRef]

10. Brand, A.; Bull, C.; Cakir, B. Vaginal stenosis in patients treated with radiotherapy for carcinoma of the cervix. Int. J. Gynecol. Cancer 2006, 16, 288-293. [CrossRef] [PubMed]

11. Yoshida, K.; Yamazaki, H.; Nakamura, S.; Masui, K.; Kotsuma, T.; Akiyama, H.; Tanaka, E.; Yoshikawa, N.; Uesugi, Y.; Shimbo, T.; et al. Role of vaginal pallor reaction in predicting late vaginal stenosis after high-dose-rate brachytherapy in treatment-naive patients with cervical cancer. J. Gynecol. Oncol. 2015, 26, 179-184. [CrossRef] [PubMed]

12. Son, C.H.; Law, E.; Oh, J.H.; Apte, A.P.; Yang, T.J.; Riedel, E.; Wu, A.J.; Deasy, J.O.; Goodman, K.A. Dosimetric Predictors of Radiation-Induced Vaginal Stenosis After Pelvic Radiation Therapy for Rectal and Anal Cancer. Int. J. Radiat. Oncol. 2015, 92, 548-554. [CrossRef]

13. Grigsby, P.W.; Russell, A.; Bruner, D.; Eifel, P.; Koh, W.-J.; Spanos, W.; Stetz, J.; Stitt, J.A.; Sullivan, J. Late injury of cancer therapy on the female reproductive tract. Int. J. Radiat. Oncol. 1995, 31, 1281-1299. [CrossRef]

14. Denton, A.S.; Maher, J. Interventions for the physical aspects of sexual dysfunction in women following pelvic radiotherapy. Cochrane Database Syst. Rev. 2003, CD003750. [CrossRef]

15. Lancaster, L. Preventing vaginal stenosis after brachytherapy for gynaecological cancer: An overview of Australian practices. Eur. J. Oncol. Nurs. 2004, 8, 30-39. [CrossRef]

16. Cancer Therapy Evaluation Program. Common Terminology Criteria for Adverse Events (CTCAE). Version 5.0, DCTC, NCI, NIH, DHHS. 2017. Available online: https:/ /Ctep.Cancer.Gov/Protocoldevelopment/Electronic_applications/Docs/CTCAE_v5 _Quick_Reference_8.5x11.Pdf (accessed on 11 January 2021).

17. Pavi, J.; Denekamp, J.; Letschert, J. Lent soma scales for all anatomic sites. Int. J. Radiat. Oncol. 1995, 31, 1049-1091. [CrossRef]

18. Sorbe, B.G.; Smeds, A.-C. Postoperative vaginal irradiation with high dose rate afterloading technique in endometrial carcinoma stage I. Int. J. Radiat. Oncol. 1990, 18, 305-314. [CrossRef]

19. Sorbe, B.; Straumits, A.; Karlsson, L. Intravaginal high-dose-rate brachytherapy for stage I endometrial cancer: A randomized study of two dose-per-fraction levels. Int. J. Radiat. Oncol. 2005, 62, 1385-1389. [CrossRef]

20. Park, H.S.; Ratner, E.S.; Lucarelli, L.; Polizzi, S.; Higgins, S.A.; Damast, S. Predictors of vaginal stenosis after intravaginal high-dose-rate brachytherapy for endometrial carcinoma. Brachytherapy 2015, 14, 464-470. [CrossRef]

21. Hintz, B.; Kagan, A.; Chan, P.; Gilbert, H.; Nussbaum, H.; Rao, A.; Wollin, M. Radiation tolerance of the vaginal mucosa. Int. J. Radiat. Oncol. 1980, 6, 711-716. [CrossRef]

22. Eifel, P.J.; Jhingran, A.; Bodurka, D.C.; Levenback, C.; Thames, H. Correlation of Smoking History and Other Patient Characteristics With Major Complications of Pelvic Radiation Therapy for Cervical Cancer. J. Clin. Oncol. 2002, 20, 3651-3657. [CrossRef] [PubMed]

23. Ferrari, F.; Forte, S.; Ardighieri, L.; Bonetti, E.; Fernando, B.; Sartori, E.; Odicino, F. Multivariate analysis of prognostic factors in primary squamous cell vulvar cancer: The role of perineural invasion in recurrence and survival. Eur. J. Surg. Oncol. 2019, 45, 2115-2119. [CrossRef]

24. Jensen, P.T.; Froeding, L.P. Pelvic radiotherapy and sexual function in women. Transl. Androl. Urol. 2015, 4, 186-205. [PubMed]

25. Gentileschi, S.; Servillo, M.; Garganese, G.; Fragomeni, S.; De Bonis, F.; Scambia, G.; Salgarello, M. Surgical therapy of vulvar cancer: How to choose the correct reconstruction? J. Gynecol. Oncol. 2016, 27, e60. [CrossRef]

26. Tan, B.-K.; Kang, G.C.-W.; Tay, E.H.; Por, Y.C. Subunit Principle of Vulvar Reconstruction: Algorithm and Outcomes. Arch. Plast. Surg. 2014, 41, 379-386. [CrossRef] [PubMed]

27. Damast, S.; Jeffery, D.D.; Son, C.H.; Hasan, Y.; Carter, J.; Lindau, S.T.; Jhingran, A. Literature Review of Vaginal Stenosis and Dilator Use in Radiation Oncology. Pr. Radiat. Oncol. 2019, 9, 479-491. [CrossRef]

28. Gondi, V.; Bentzen, S.M.; Sklenar, K.L.; Dunn, E.F.; Petereit, D.G.; Tannehill, S.P.; Straub, M.; Bradley, K.A. Severe Late Toxicities Following Concomitant Chemoradiotherapy Compared to Radiotherapy Alone in Cervical Cancer: An Inter-era Analysis. Int. J. Radiat. Oncol. 2012, 84, 973-982. [CrossRef]

29. Law, E.; Kelvin, J.F.; Thom, B.; Riedel, E.; Tom, A.; Carter, J.; Alektiar, K.M.; Goodman, K.A. Prospective study of vaginal dilator use adherence and efficacy following radiotherapy. Radiother. Oncol. 2015, 116, 149-155. [CrossRef] [PubMed]

30. Vagal, M.R.; Shrivastava, S.K.; Mahantshetty, U.; Gupta, S.; Chopra, S.; Engineer, R.; Maheshwari, A.; Buduk, A. A Retro-spective Study of Vaginal Stenosis Following Treatment of Cervical Cancers and the Effectiveness of Rehabilitation In-terventions. Int. J. Med. Health Sci. 2017, 11, 94-99. 
31. Stahl, J.M.; Qian, J.M.; Tien, C.J.; Carlson, D.J.; Chen, Z.; Ratner, E.S.; Park, H.S.; Damast, S. Extended duration of dilator use beyond 1 year may reduce vaginal stenosis after intravaginal high-dose-rate brachytherapy. Support. Care Cancer 2018, 27, 1425-1433. [CrossRef]

32. Miles, T.; Johnson, N. Vaginal dilator therapy for women receiving pelvic radiotherapy. Cochrane Database Syst. Rev. 2014, 2014, CD007291. [CrossRef]

33. Sydney Gynaecological Oncology Group. Vaginal Dilator Therapy: Guidelines for the Use of Vaginal Dilators in Women Receiving Pelvic Radiotherapy and Brachytherapy Treatments. Sydney Local Health District. Available online: http:/ / www.Slhd. Nsw.Gov.Au/Services/Sgog/VD_Therapy.Html (accessed on 2 February 2021).

34. Cancer Institute NSW. EviQ. Supporting Document-Management of Radiation Induced Vaginal Stenosis. Available online: https:/ / www.Eviq.Org.Au/Protocol/Tabid/66/Categoryid/180/Id/1867/Supporting+Document+-+Management+of+ Radiation+Induced+Vaginal+Stenosis.Aspx (accessed on 2 February 2021).

35. Katz, A. Interventions for Sexuality After Pelvic Radiation Therapy and Gynecological Cancer. Cancer J. 2009, 15, 45-47. [CrossRef]

36. Matos, S.R.D.L.; Cunha, M.L.R.; Podgaec, S.; Weltman, E.; Centrone, A.F.Y.; Mafra, A.C.C.N. Consensus for vaginal stenosis prevention in patients submitted to pelvic radiotherapy. PLoS ONE 2019, 14, e0221054. [CrossRef] [PubMed]

37. Gerdin, B.; Hällgren, R. Dynamic role of hyaluronan (HYA) in connective tissue activation and inflammation. J. Intern. Med. 1997, 242, 49-55. [CrossRef] [PubMed]

38. Necas, J.; Bartosikova, L.; Brauner, P.; Kolar, J. Hyaluronic acid (hyaluronan): A review. Vet. Med. 2008, 53, 397-411. [CrossRef]

39. Cosentino, D.; Piro, F. Hyaluronic acid for treatment of the radiation therapy side effects: A systematic review. Eur. Rev. Med. Pharmacol. Sci. 2018, 22, 7562-7572.

40. Costantino, D.; Guaraldi, C. Effectiveness and safety of vaginal suppositories for the treatment of the vaginal atrophy in postmenopausal women: An open, non-controlled clinical trial. Eur. Rev. Med. Pharmacol. Sci. 2009, 12, 411-416.

41. Chen, J.; Geng, L.; Song, X.; Li, H.; Giordan, N.; Liao, Q. Evaluation of the Efficacy and Safety of Hyaluronic Acid Vaginal Gel to Ease Vaginal Dryness: A Multicenter, Randomized, Controlled, Open-Label, Parallel-Group, Clinical Trial. J. Sex. Med. 2013, 10, 1575-1584. [CrossRef]

42. Ekin, M.; Yaşar, L.; Savan, K.; Temur, M.; Uhri, M.; Gencer, I.; Kıvanç, E. The comparison of hyaluronic acid vaginal tablets with estradiol vaginal tablets in the treatment of atrophic vaginitis: A randomized controlled trial. Arch. Gynecol. Obstet. 2010, 283, 539-543. [CrossRef]

43. Cassaro, N.; Bianca, G.; Meli, M.T. Efficacy of Topical Therapy with Vaginal Ovules Containing Hyaluronic Acid in the Treatment of the Side Effects of Radiotherapy and Chemotherapy on the Vagina. G. Ital. Ostet. E Ginecol. 2009, 31, 367-372.

44. DiNicola, S.; Pasta, V.; Costantino, D.; Guaraldi, C.; Bizzarri, M. Hyaluronic acid and vitamins are effective in reducing vaginal atrophy in women receiving radiotherapy. Miner. Ginecol. 2015, 67, 10.

45. Markowska, J.; Madry, R.; Markowska, A. The effect of hyaluronic acid (Cicatridine) on healing and regeneration of the uterine cervix and vagina and vulvar dystrophy therapy. Eur. J. Gynaecol. Oncol. 2011, 32, 65-68.

46. Carter, J.; Baser, R.E.; Goldfrank, D.J.; Seidel, B.; Milli, L.; Stabile, C.; Canty, J.; Saban, S.; Goldfarb, S.; Dickler, M.N.; et al. A single-arm, prospective trial investigating the effectiveness of a non-hormonal vaginal moisturizer containing hyaluronic acid in postmenopausal cancer survivors. Support. Care Cancer 2020, 29, 1-12. [CrossRef] [PubMed]

47. Delia, P.; Sansotta, G.; Pontoriero, A.; Iati, G.; De Salvo, S.; Pisana, M.; Potami, A.; Lopes, S.; Messina, G.; Pergolizzi, S. Clinical Evaluation of Low-Molecular-Weight Hyaluronic Acid-Based Treatment on Onset of Acute Side Effects in Women Receiving Adjuvant Radiotherapy after Cervical Surgery: A Randomized Clinical Trial. Oncol. Res. Treat. 2019, 42, 217-223. [CrossRef]

48. Laliscia, C.; Delishaj, D.; Fabrini, M.G.; Gonnelli, A.; Morganti, R.; Perrone, F.; Tana, R.; Paiar, F.; Gadducci, A. Acute and late vaginal toxicity after adjuvant high-dose-rate vaginal brachytherapy in patients with intermediate risk endometrial cancer: Is local therapy with hyaluronic acid of clinical benefit? J. Contemp. Brachyther. 2016, 8, 512-517. [CrossRef] [PubMed]

49. Athanasiou, S.; Pitsouni, E.; Grigoriadis, T.; Zacharakis, D.; Falagas, M.E.; Salvatore, S.; Protopapas, A.; Loutradis, D. Microablative fractional $\mathrm{CO}_{2}$ laser for the genitourinary syndrome of menopause: Up to 12-month results. Menopause 2019, 26, $248-255$. [CrossRef]

50. Gambacciani, M.; Levancini, M.; Russo, E.; Vacca, L.; Simoncini, T.; Cervigni, M. Long-term effects of vaginal erbium laser in the treatment of genitourinary syndrome of menopause. Climacteric 2018, 21, 148-152. [CrossRef]

51. Cruz, V.L.; Steiner, M.L.; Pompei, L.M.; Strufaldi, R.; Fonseca, F.L.A.; Santiago, L.H.S.; Wajsfeld, T.; Fernandes, C.E. Randomized, double-blind, placebo-controlled clinical trial for evaluating the efficacy of fractional $\mathrm{CO}_{2}$ laser compared with topical estriol in the treatment of vaginal atrophy in postmenopausal women. Menopause 2018, 25, 21-28. [CrossRef]

52. Perino, A.; Calligaro, A.; Forlani, F.; Tiberio, C.; Cucinella, G.; Svelato, A.; Saitta, S.; Calagna, G. Vulvo-vaginal atrophy: A new treatment modality using thermo-ablative fractional $\mathrm{CO}_{2}$ laser. Maturitas 2015, 80, 296-301. [CrossRef]

53. Athanasiou, S.; Pitsouni, E.; Douskos, A.; Salvatore, S.; Loutradis, D.; Grigoriadis, T. Intravaginal energy-based devices and sexual health of female cancer survivors: A systematic review and meta-analysis. Lasers Med. Sci. 2019, 35, 1-11. [CrossRef]

54. Perrone, A.M.; Tesei, M.; Ferioli, M.; De Terlizzi, F.; Della Gatta, A.N.; Boussedra, S.; Dondi, G.; Galuppi, A.; Morganti, A.G.; De Iaco, P. Results of a Phase I-II Study on Laser Therapy for Vaginal Side Effects after Radiotherapy for Cancer of Uterine Cervix or Endometrium. Cancers 2020, 12, 1639. [CrossRef] 
55. Quick, A.M.; Dockter, T.; Le-Rademacher, J.; Salani, R.; Hudson, C.; Hundley, A.; Terstriep, S.; Streicher, L.; Faubion, S.; Loprinzi, C.L.; et al. Pilot study of fractional $\mathrm{CO}_{2}$ laser therapy for genitourinary syndrome of menopause in gynecologic cancer survivors. Maturitas 2021, 144, 37-44. [CrossRef]

56. American College of Obstetricians and Gynecologists. ACOG Practice Bulletin No. 141: Management of Menopausal Symptoms. Obstet. Gynecol. 2014, 123, 202-216. [CrossRef]

57. Santen, R.J.; Pinkerton, J.V.; Conaway, M.; Ropka, M.; Wisniewski, L.; Demers, L.; Klein, K.O. Treatment of urogenital atrophy with low-dose estradiol: Preliminary results. Menopause 2002, 9, 179-187. [CrossRef]

58. Hofsjö, A.; Bohm-Starke, N.; Bergmark, K.; Masironi, B.; Sahlin, L. Sex steroid hormone receptor expression in the vaginal wall in cervical cancer survivors after radiotherapy. Acta Oncol. 2019, 58, 1107-1115. [CrossRef]

59. Shim, S.-H.; Lee, S.J.; Kim, S.-N. Effects of hormone replacement therapy on the rate of recurrence in endometrial cancer survivors: A meta-analysis. Eur. J. Cancer 2014, 50, 1628-1637. [CrossRef]

60. Edey, K.A.; Rundle, S.; Hickey, M. Hormone replacement therapy for women previously treated for endometrial cancer. Cochrane Database Syst. Rev. 2018, 5, CD008830. [CrossRef]

61. Sinno, A.; Pinkerton, J.; Febbraro, T.; Jones, N.; Khanna, N.; Temkin, S.; Iglesias, D.; Pothuri, B. Hormone therapy (HT) in women with gynecologic cancers and in women at high risk for developing a gynecologic cancer: A Society of Gynecologic Oncology (SGO) clinical practice statement. Gynecol. Oncol. 2020, 157, 303-306. [CrossRef]

62. Ploch, E. Hormonal replacement therapy in patients after cervical cancer treatment. Gynecol. Oncol. 1987, 26, 169-177. [CrossRef] 